\title{
Redescription of Cichlidogyrus philander (Monogenea, Ancyrocephalidae) using scanning electron microscopy (SEM) and molecular analysis
}

\author{
Patience C Igeh ${ }^{\mathrm{a}, \mathrm{b}}$, Quinton M Dos Santos ${ }^{\mathrm{a}}$, and Annemariè Avenant-Oldewage ${ }^{\mathrm{a},{ }^{*}}$ \\ a Department of Zoology, University of Johannesburg, PO Box 524, Auckland Park 2006, Johannesburg, South Africa \\ b Department of Microbiology, Plateau State University, PO Box 2012, Jos, Nigeria
}

Received 26 June 2017, Accepted 2 November 2017, Published online 1 December 2017

\begin{abstract}
The sclerotized structures of monogeneans have traditionally been studied by light microscopy and different staining techniques. Recently, enzymatic digestion followed by scanning electron microscopy (SEM) has enabled the examination of structural details not visible with light microscopy. In order to obtain better, and more accurate, morphological information on sclerotized structures not affected by mounting medium or cover slip pressure, the sclerites of Cichlidogyrus philander Douëllou, 1993 (Monogenea, Ancyrocephalidae), collected from Pseudocrenilabrus philander (Weber, 1897), were redescribed using SEM. Parasites were collected from Padda Dam, Gauteng, South Africa and soft tissue was digested to release the sclerotized structures. The digested tissue also provided sufficient genetic material for molecular characterization of this species. Cichlidogyrus philander is characterised by a penis with a sharp, curved, lateral termination, an accessory piece with a hook-like extremity that may appear forked terminally, and lack of a visible vagina. The transverse bars have concave and convex surfaces with ribs on the concave surface. The dorsal bar bears fenestrations at the base of the auricles and the ventral and dorsal gripi are dissimilar. Furthermore, the large first pair of uncinuli shows lateral wings on the left side of the base. On top of this wing, a ball-like structure with a small fenestration is visible. Genetic characters derived from the $28 \mathrm{~S} \mathrm{rDNA}$, the COI mitochondrial DNA and ITS1 rDNA regions distinguish C. philander from all other Cichlidogyrus sequenced species.
\end{abstract}

Keywords: Pseudocrenilabrus philander, sclerites, molecular analysis, South Africa, Padda Dam

Résumé - Redescription de Cichlidogyrus philander (Monogenea, Ancyrocephalidae) par microscopie électronique à balayage (MEB) et analyse moléculaire. Les structures sclérifiées des monogènes ont traditionnellement été étudiées par microscopie optique et différentes techniques de coloration. Récemment, la digestion enzymatique suivie par la microscopie électronique à balayage (MEB) a permis d'examiner des détails structuraux non visibles en microscopie optique. Les sclérites de Cichlidogyrus philander Douëllou, 1993 (Monogenea, Ancyrocephalidae), collecté chez Pseudocrenilabrus philander, sont redécrites par MEB afin d'obtenir une information morphologique meilleure et plus précise des structures sclérifiées, non affectée par le milieu de montage. Les parasites ont été recueillis à Padda Dam, Gauteng, Afrique du Sud et les tissus mous ont été digérés pour libérer les structures sclérifiées. Le tissu digéré a fourni également suffisamment de matériel génétique pour la caractérisation moléculaire de l'espèce. Cichlidogyrus philander se caractérise par un pénis avec une terminaison latérale courbée et pointue, une pièce accessoire avec une extrémité en forme de crochet qui peut apparaître fourchue terminalement, et l'absence de vagin visible. Les barres transversales ont des surfaces concaves et convexes avec des nervures sur les surfaces concaves. La barre dorsale porte des fenestrations à la base des oreillettes et les gripi ventraux et dorsaux sont dissemblables. En outre, la première grande paire d'uncinuli montre des ailes latérales sur le côté gauche de la base. Au sommet de cette aile, une structure en forme de boule avec une petite fenestration est visible. Les caractères génétiques dérivés de l'ADNr 28S, de l'ADN mitochondrial COI et de l'ADNr ITS1 distinguent $C$. philander de toutes les autres espèces séquencées de Cichlidogyrus.

\footnotetext{
*Corresponding author: aoldewage@uj.ac.za
} 


\section{Introduction}

Cichlidogyrus philander Douëllou, 1993 is a monogenean ectoparasite occurring on the gills of Pseudocrenilabrus philander (Weber, 1897). It was first described by Douëllou from Lake Kariba, Zimbabwe [3]. The species was later found in the Padda Dam, Gauteng, South Africa $[15,16]$ and apart from these two sites, $C$. philander has not been documented in any other locality. Cichlidogyrus Paperna, 1960 includes more than 100 species and has a wide distribution [13]. Like other monogeneans, the members of this genus use a specialized, posteriorly situated organ, the haptor, to attach themselves to the host [24,25]. In Cichlidogyrus, the haptor is composed of hooks and transverse bars [25,27] and these structures form a functional unit and have adapted to specific sites (microenvironment) within their host [37].

In monogenean morphological taxonomy, copulatory organs and haptoral parts have been widely used for identification and remain a key diagnostic feature $[14,20]$. In most monogeneans, the morphology of the haptoral sclerites is used for genus determination and the morphology of the male apparatus (comprising a penis and accessory piece) for species identification [28]. These parts have traditionally been studied using light microscopy and various staining techniques, enabling morphological descriptions and morphometry. However, classic techniques based on light microscopy do not allow detailed examination of this sclerotized structure [2]. The fixation and preparation, as well as the amount of pressure applied to the coverslip, may interfere with the interpretation and measurement of these structures $[2,6,22]$. An example is found in Fankoua et al. [6], where they mentioned that the type of fixative/ preservative and mounting medium used has an effect on the size and shape of monogenean sclerites. They observed that the use of Hoyer's medium clears tissue, softens the sclerites and makes them lie flat under the cover slip pressure but on the contrary, the sclerites become enlarged and deformed, which does not accurately reflect the shape and size of these structures. Mo and Appleby found that sclerotized parts could be exposed by enzymatic digestion and subsequently examined by scanning electron microscopy (SEM) [22]. Subsequent authors modified the method in various ways $[2,7,10,11,31,32]$. Shinn et al. mentioned that, in addition to releasing the sclerites from the tissue, digestion makes it possible for the sclerites to lie flat, allowing more accurate visualizations and measurements [31]. The original description of $C$. philander was limited to light microscopy [3]. In this study, the sclerotized parts of $C$. philander are redescribed using SEM for the purpose of obtaining better and more accurate data on the morphology of the sclerotized structures, not affected by mounting medium or cover slip pressure, to provide additional information on C. philander. Furthermore, a molecular analysis is performed to examine the distinctiveness of this taxon.

\section{Materials and methods Collection of fish and parasites}

Following approval from the Ethics Committee of the University of Johannesburg's Faculty of Science, and obtaining a permit from Nature Conservation in Gauteng, South Africa (permit numbers: CPE2-000116 and CPE3000134), 20 P. philander were captured by electro-narcosis and hand nets from Padda Dam (20 $\left.10^{\prime} \mathrm{S} ; 17^{\circ} 59^{\prime} \mathrm{E}\right)$, which is located on University of Johannesburg grounds, Gauteng. Captured fish were transported to the laboratory where they were kept in a holding tank with aerated dam water. Each fish was then weighed, measured and euthanised by a single cut through the spinal cord. The gills were removed using dissection scissors and tweezers and examined with a Zeiss stemi 350 compact-stereomicroscope. The parasites were gently removed with a preparation needle.

\section{Morphological study}

Collected parasites were fixed in $70 \%$ ethanol and mounted individually in a drop of glycerine-ammoniumpicrate (GAP) on a slide [18]. The preparation was then covered with a coverslip and sealed with nail varnish. Some specimens were stained with Horen's trichrome as described in the Manual of Veterinary Parasitological Techniques [19], cleared, mounted in a drop of lactophenol and sealed with nail varnish.

Photomicrographs and measurements were obtained using a Zeiss Axioplan 2 Imaging light microscope with Axiovision 4.7.2 software; measurements were taken as proposed by Gussev [9]. The numbering of haptoral pieces (I-VII) was adapted after Euzet and Prost [5] and the method of naming is that proposed by Pariselle and Euzet [26]. Measurements were taken as shown in Figure 1 and are given in $\mu \mathrm{m}$ as Minimum - Maximum - Average (Standard Deviation) in Table 1. Data from this study were compared with the original species description by Douëllou [3]. Voucher specimens were deposited in the Iziko museum (SAMC-A089303; SAMC-A089304) and the Muséum National d'Histoire Naturelle, Paris, France (accession number MNHN HEL734 - HEL735).

For SEM of the exterior of the parasite, ten specimens previously preserved in $70 \%$ ethanol were dehydrated in a graded series of ethanol and hexamethyldisilazane after Dos Santos et al. [1]. The dehydrated specimens were mounted on a strip of carbon conductive tape that was fixed to an SEM stub. Specimens were sputter coated with gold using an Emscope SC500 sputter coater (Quorum Technologies, Lewes, U.K.) and examined with a TESCAN Vega 3 LMH SEM (Brno, Czech Republic) at 6$10 \mathrm{kV}$ acceleration voltage. For SEM of isolated hard parts, 20 parasites freshly removed from the gills of 5 fish were each placed individually on a concavity slide and digested with $0.5 \mu$ l of digestion buffer (9 parts ALT buffer: 1 part proteinase K) from a DNeasy ${ }^{\circledR}$ Blood and Tissue kit (QIAGEN, Manchester, U.K.) after Dos Santos and Avenant-Oldewage [2]. Digestion of parasites was 

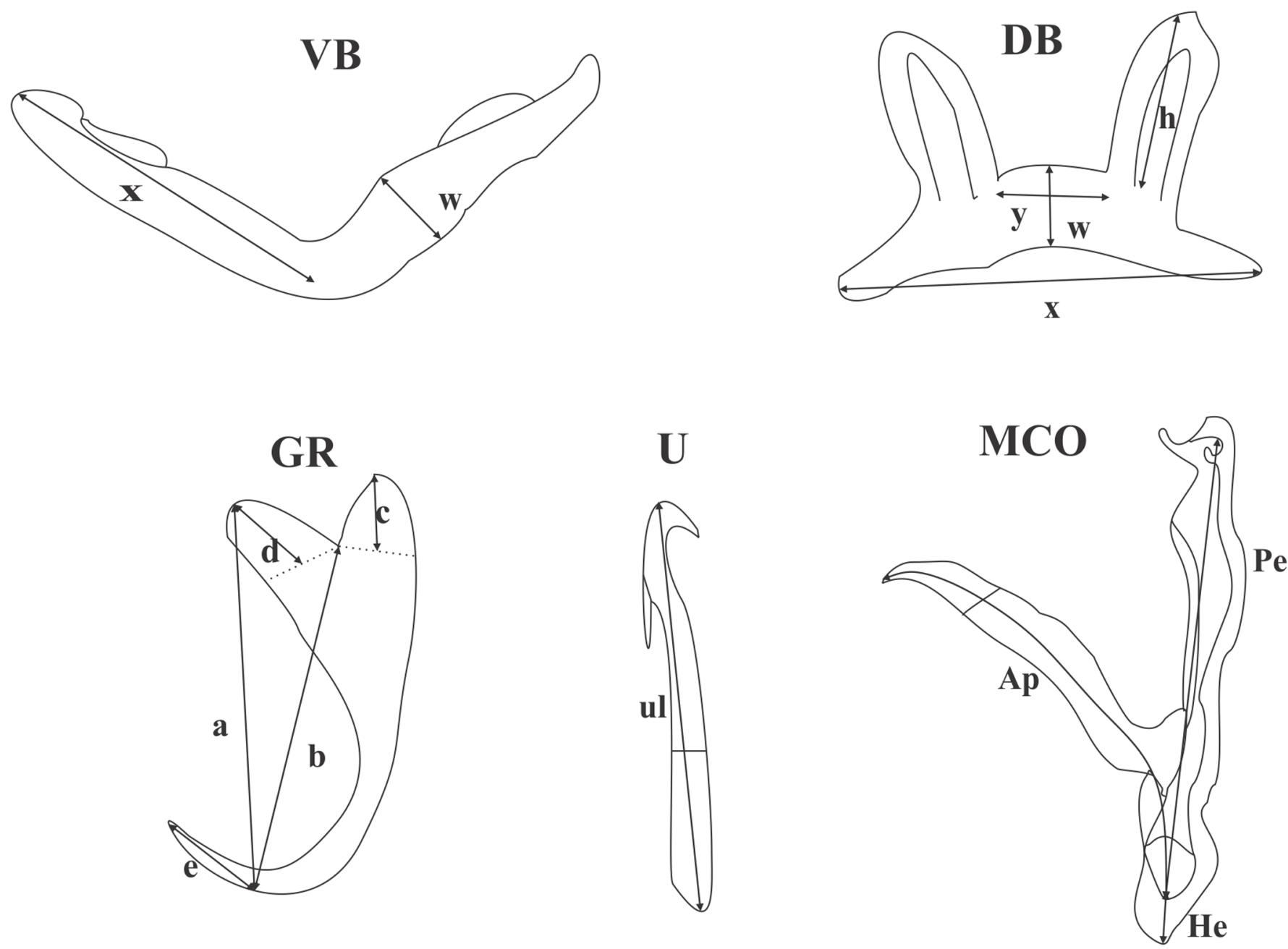

Figure 1. Measurements used in this study. Abbreviations: VB ventral transverse bar: $\mathbf{x}$ length of one ventral bar branch, $\mathbf{w}$ ventral bar maximum width; DB dorsal transverse bar: $\mathbf{h}$ length of auricle, $\mathbf{x}$ total length, $\mathbf{y}$ distance between auricles, $\mathbf{w}$ maximum width; GR gripus: a total length of gripus, $\mathbf{b}$ blade length, c outer root length, $\mathbf{d}$ inner root length, e point length; MCO male copulatory organ: Ap accessory piece length, Pe penis total length, He heel length; U uncinulus: ul uncinulus length.

observed with a stereo microscope and to prevent the crystallisation of the digestion buffer, small volumes of distilled water were added. This addition of distilled water also allowed for residual buffer to be removed using a micropipette. Usually, 5-6 rounds of adding water and pipetting out the residual buffer and digested material were sufficient to wash out the residual buffer. The digested material and buffer were collected in a $1.5 \mu \mathrm{l}$ microcentrifuge tube and stored for DNA analysis. The samples were then dried overnight in a Sanpla dry keeper desiccator cabinet (Kitaku, Osaka, Japan), sputter coated with gold, and examined using a Vega 3 LMH SEM at 6$10 \mathrm{kV}$.

\section{Molecular analysis}

Using the digested tissue from specimens as outlined in the above procedure, genetic material was extracted using a DNeasy ${ }^{\circledR}$ tissue kit (QIAGEN, Manchester, U.K.), according to the manufacturer's instructions. For this study, the large subunit of ribosomal DNA (28S), first internal transcribed spacer (ITS1) rDNA, and the mitochondrial cytochrome oxidase c subunit I (COI) fragments were used. Extracted genetic material from each specimen was used in triplicate for the $28 \mathrm{~S}$, ITS1 and COI amplifications, respectively. The $28 \mathrm{~S}$ rDNA was amplified using primers C1 (forward; 5'-ACCCGCTGAATTTAAGCAT-3') and D2 (reverse; 5'-TGGTCCGTGTTTCAAGAC-3'), according to the amplification protocol of Messu Mandeng et al. [21]. For ITS1, the ITS1A (5'-GTAACAAGGTTTCCGTAGGTG-3') and ITSR3A (5'-GAGCCGAGTGATCCACC-3') primers were used, and the primers ASmit1 (5'-TTTTTTGGGCATCCTGAGGTTTAT-3') and Schisto3 (5'TAATGCATMGGAAAAAAACA-3') were used to target the COI region. The amplification protocol of Vanhove et al. [36] was used for both ITS1 and COI (excluding the use of nested PCR). Verification of successful amplicons was done on a $1 \%$ agarose gel, impregnated with GelRed ${ }^{\circledR}$ (Biotium) and visualized with a UV transilluminator. For each marker, 10 amplicons were sequenced using standard BigDye chemistry, and analyzed on an ABI 3137 
Table 1. Measurement (in $\mu \mathrm{m}$ ) of Cichlidogyrus philander parasitic on Pseudocrenilabrus philander in Padda Dam, compared to measurements provided by Douëllou (1993).

\begin{tabular}{|c|c|c|c|c|c|c|c|}
\hline \multirow[b]{2}{*}{ Structure } & \multicolumn{4}{|c|}{$\begin{array}{c}\text { Measurements }(\mu \mathrm{m}) \\
\text { Douëllou }(1993) \\
(\mathrm{n}=15)\end{array}$} & \multicolumn{3}{|c|}{$\begin{array}{l}\text { Measurements }(\mu \mathrm{m}) \\
\text { Present study } \\
(\mathrm{n}=30)\end{array}$} \\
\hline & Min & Max & & Ave. & Min & Max & Ave. $( \pm \mathrm{SD})$ \\
\hline \multicolumn{8}{|l|}{ Body: } \\
\hline Length & 260 & 400 & & 321 & 252 & 473 & $341(65)$ \\
\hline Width & 55 & 80 & & 69 & 52 & 111 & $93(11)$ \\
\hline Pharynx * & - & - & & - & 17 & 20 & $19(1)$ \\
\hline \multicolumn{8}{|l|}{ Ventral bar (VB): } \\
\hline w: maximum width of one bar branch & 2 & 5 & & 3 & 4 & 8 & $5(1)$ \\
\hline $\mathrm{x}$ : Length of one bar branch & 25 & 29 & & 28 & 19 & 39 & $29(5)$ \\
\hline \multicolumn{8}{|l|}{ Dorsal Bar (DB): } \\
\hline h: Length of auricle & 10 & 12 & & 21 & 8 & 17 & $10(2)$ \\
\hline w: Maximum width & 4 & 6 & & 5 & 3 & 9 & $6(1)$ \\
\hline $\mathrm{x}$ : Total length & 24 & 31 & & 28 & 26 & 39 & $32(1)$ \\
\hline y: Distance between auricles & 7 & 12 & & 9 & 3 & 17 & $10(3)$ \\
\hline \multicolumn{8}{|l|}{ Ventral gripus (VB): } \\
\hline a: Total length of gripus & 28 & 32 & & 30 & 29 & 33 & $31(1)$ \\
\hline b: Blade length & 23 & 27 & & 25 & 23 & 30 & $27(2)$ \\
\hline c: Outer root length & 4 & 7 & & 5 & 4 & 8 & $6(1)$ \\
\hline d: Inner root length & 8 & 12 & & 10 & 8 & 13 & $11(1)$ \\
\hline e: Point Length & 8 & 11 & & 10 & 5 & 12 & $9(2)$ \\
\hline \multicolumn{8}{|l|}{ Dorsal gripus (DG): } \\
\hline a: Total length of gripus & 29 & 36 & & 33 & 29 & 39 & $34(3)$ \\
\hline b: Blade length & 18 & 23 & & 21 & 17 & 26 & $22(2)$ \\
\hline c: Outer root length & 3 & 7 & & 5 & 4 & 10 & $7(2)$ \\
\hline $\mathrm{d}$ : Inner root length & 12 & 16 & & 14 & 10 & 18 & $15(2)$ \\
\hline e: Point Length & 6 & 9 & & 7 & 4 & 9 & $7(1)$ \\
\hline \multicolumn{8}{|l|}{ Uncinuli (U) Length: } \\
\hline $\mathrm{I}$ & 22 & 24 & & 23 & 15 & 27 & $23(3)$ \\
\hline II ** & 10 & 11 & & 10 & 6 & 11 & $9(1)$ \\
\hline III ***(4) & 19 & 20 & & 16 & 11 & 22 & $17(4)$ \\
\hline $\mathrm{IV} * * *(3)$ & 15 & 17 & & 20 & 13 & 24 & $19(3)$ \\
\hline $\mathrm{V}$ & 22 & 25 & & 23 & 21 & 28 & $24(2)$ \\
\hline VI & 20 & 22 & & 21 & 17 & 27 & $22(2)$ \\
\hline VII & 18 & 20 & & 19 & 17 & 25 & $20(2)$ \\
\hline \multicolumn{8}{|l|}{ MCO: } \\
\hline Ap: Accessory piece length & 27 & 35 & & 32 & 27 & 47 & $40(6)$ \\
\hline He: Heel length & & & - & 3 & 2 & 6 & $4(1)$ \\
\hline Pe: Penis Length & 44 & 50 & & 46 & 38 & 49 & $45(3)$ \\
\hline
\end{tabular}

Automated Sequencer (Applied Biosystems, Foster City, CA, U.S.A). The obtained sequences were aligned and edited in MEGA 6 [35]. For the ITS1 and 28S sequences, 8 sequences from individuals whose trace files were of sufficiently good quality were phased using the default settings for the PHASED algorithm [33] in DnaSP v.5 [17] to produce 16 alleles. Closely related sequences (100) for Cichlidogyrus spp. and Scutogyrus spp. were obtained from GenBank using BLAST and aligned to the sequences produced in this study with MUSCLE [4] as implemented in MEGA 6 [35], followed by manual inspection. Sequences that covered less than $70 \%$ of the alignment were omitted from these analyses to improve accuracy. Pairwise distances between sequences were computed on MEGA 6 [35] using uncorrected $p$-distances. Identical sequences and haplotypes differing less than 0.01 [36] were removed. Phylogenies were reconstructed using the maximum likelihood (ML) method based on the Tamura-Nei model [34] with initial trees obtained by applying NeighborJoin and BioNJ algorithms to a matrix estimated using 
the Maximum Composite Likelihood (MCL) approach; and the maximum parsimony (MP) method using the subtree-pruning-regrafting (SPR) algorithm [23]. Furthermore, 1000 bootstrap replicates were used to assess the robustness of all the resulting topologies. The analysis involved 33,42 , and 43 sequences with a total of 563,239 and 320 positions in the final data sets for the 28S, ITS1 and COI markers, respectively. Sequences of the most distant Cichlidogyrus taxa from that of $C$. philander were used to root the phylogenies. The genetic distances and phylogenetic trees are presented in the appendixes to the manuscript (unidentified taxa removed from the distance tables for ease of representation).

\section{Results}

\section{Light microscopy}

The authors believe the drawings provided by Douëllou [3] are still sufficient and relevant, and were used as a reference. Measurements recorded are shown in Table 1 and are compared with those of Douëllou [3]. Using light microscopy, the male copulatory organ is seen to consist of a penis and accessory piece (Fig. 2A, B). The penis is straight and broad arising from a reduced basal portion with a heel. It is constricted at about $1 / 3$ of its length, while the accessory piece is approximately as long and wide as the penis (Fig. 2A, B). The sclerotized parts of the haptor (Fig. 2C) are small with two transverse bars, two pairs of large gripi (anchors) and seven pairs of uncinuli (marginal hooks). The transverse bars are the ventral bar which is short, curved with slight constrictions towards extremities and a small dorsal bar that is slightly arched with two auricles. The gripi (anchors) are composed of the ventral and dorsal gripi, which have caps on the end of their roots. The ventral gripi are short with a narrow outer root and a wider inner root, a narrow base, long thin shaft, and long sharp point, while the dorsal gripi are longer and different in shape, with a slender base, short shaft and point and the outer root well developed. The seven pairs of uncinuli (hooklets) follow the basic morphology of monogenean marginal hooks, with each hook made up of three regions: a solid base, a relatively narrow, solid shaft, and a sickle-shaped termination [29]. These features agree with the initial description of the species using light microscopy.

\section{Redescription based on SEM}

\section{Male copulatory organ}

When digested, the male copulatory organ (MCO) shows the distal part of the penis forming a curve of almost $360^{\circ}$, which ends in a sharp, lateral termination. The MCO shows a distinct opening near its base (Fig. 3A, B). The accessory piece, however, has a hook-like extremity which may appear forked terminally (Fig. 3A insert). SEM of the exterior of the parasite (MCO within tissue), from the lateral view shows only the penis extending out of the parasites tissue with the penis looking like a tight fist
(Fig $3 \mathrm{C}$ ), while the contralateral view shows an opening at the midpoint of the lateral termination (Fig. 3D),

\section{Haptoral sclerites}

We were able to view both dorsal and ventral surfaces of the transverse bars. The dorsal (convex) surface of the ventral bar has serrated or tooth-like plates arising at the point of constriction near the extremities (Fig. 4A); these plates appear to be more serrated on the dorsal surface than on the ventral (concave) surface (Fig. 4B). The ventral surface shows a fold at the extremities, a depression and ribs (Fig. 4B). The ventral (concave) surface of the dorsal bar also has ribs and a fenestration at the base of each auricle (Fig. 4C); the dorsal (convex) surface lacks these structures but shows the point of attachment of the auricles to the dorsal bar (Fig. 4D). The first pair of uncinuli are stout and large and have a lateral wing on one side of their base; on top of the lateral wing, a ball-like structure with a small fenestration is visible (Fig. 5C). All sclerites were observed with SEM; however, no additional information was obtained for some of the structures as can be seen in Figures 5A, B and D.

\section{Molecular analysis}

For each marker, at least 8 of the 10 aplicons sequenced provided sequences of sufficiently good quality to allow for proper analysis (GenBank accession numbers: 28S MG279691-MG279698; ITSI MG250200-MG250207; COI MG288503-MG288510). Little to no variation was observed for these three markers, only polymorphic sites were present in the rDNA sequences and thus no intraspecific variation was seen for $C$. philander. The two analytical methods, ML and MP produced similar phylogenetic trees for the three markers. Therefore, the ML trees were used as representatives for both the $28 \mathrm{~S}$ (Appendix 1.1) and ITS1 (Appendix 1.2), while the MP tree was used for COI (Appendix 1.3). Alignment with published sequences for the $28 \mathrm{~S}$ rDNA showed an uncorrected $p$-distance of $3.16 \%-6.15 \%$ between $C$. philander and other Cichlidogyrus taxa, with Cichlidogyrus njinei Pariselle, Bilong Bilong and Euzet, 2003 (HE792775) having the lowest, and Cichlidogyrus pouyaudi Pariselle and Euzet, 1994 (HQ010039) having the highest divergence value from $C$. philander. There was no intraspecific variation recorded for this marker. Interspecific distance values ranged from $0.18 \%-8.08 \%$ (Appendix 2.1). The ITS1 region showed an uncorrected p-distance ranging from $12.97 \%$ to $20.08 \%$ between $C$. philander and other taxa, with an unidentified Cichlidogyrus sp. (KT037335) having the lowest sequence divergence, while another unidentified Cichlidogyrus sp. (KT037321) showed the highest sequence divergence from the study taxon. Intraspecific distances of $1.26 \%$ for Cichlidogyrus tiberianus Paperna, 1960 and $2.09 \%$ for Cichlidogyrus acerbus Dossou, 1982, and interspecific distances of $1.26 \%-20.92 \%$ were observed for this maker (Appendix 2.2). For COI, the lowest uncorrected 

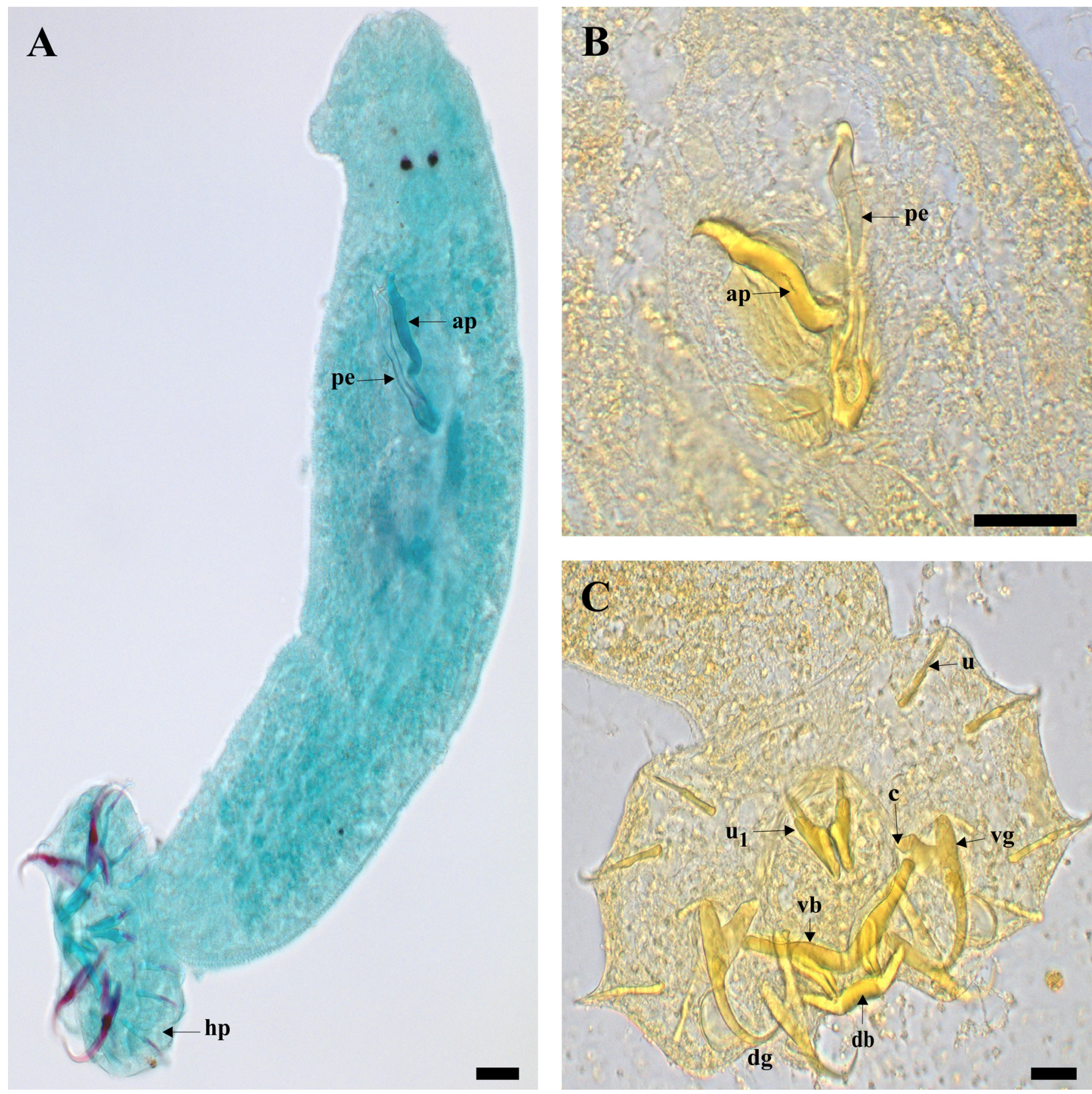

Figure 2. Light micrographs: A Whole mount of Cichlidogyrus philander stained with Horen's trichrome; B GAP-stained MCO; C GAP-stained haptor. Abbreviations: ap accessory piece; c cap; db dorsal bar; $\mathbf{d g}$ dorsal gripus; hp haptors; pe penis; $\mathbf{u}$ uncinulus; $\mathbf{u}_{\mathbf{1}} 1$ st uncinulus; $\mathbf{v b}$ ventral bar; vg ventral gripus. Scale-bars: A-B, $20 \mu \mathrm{m} ; \mathrm{C}, 10 \mu \mathrm{m}$.

p-distance $(20.31 \%)$ from C. philander was seen for Cichlidogyrus sp. (KT037383) and Cichlidogyrus casuarinus Pariselle, Muterezi Bukinga and Vanhove, 2015 (KX007849), while the highest sequence divergence (25.00\%) was observed between the study taxon and an unidentified Cichlidogyrus sp. (KT037369). Intraspecific distances $3.13 \%$ (between $C$. casuarinus species) and interspecific distances of $1.25 \%$ to $25.31 \%$ were seen for this marker (Appendix 2.3). For 28S rDNA, C. philander forms a sister taxon to a clade containing most other taxa, while for the other two markers, this species groups sister to C. casuarinus (COI) and Cichlidogyrus sp. KT037335 (ITS1).

\section{Diagnosis}

Based on SEM study, C. philander was found to have a large penis that ends in an almost $360^{\circ}$ curve, with an 

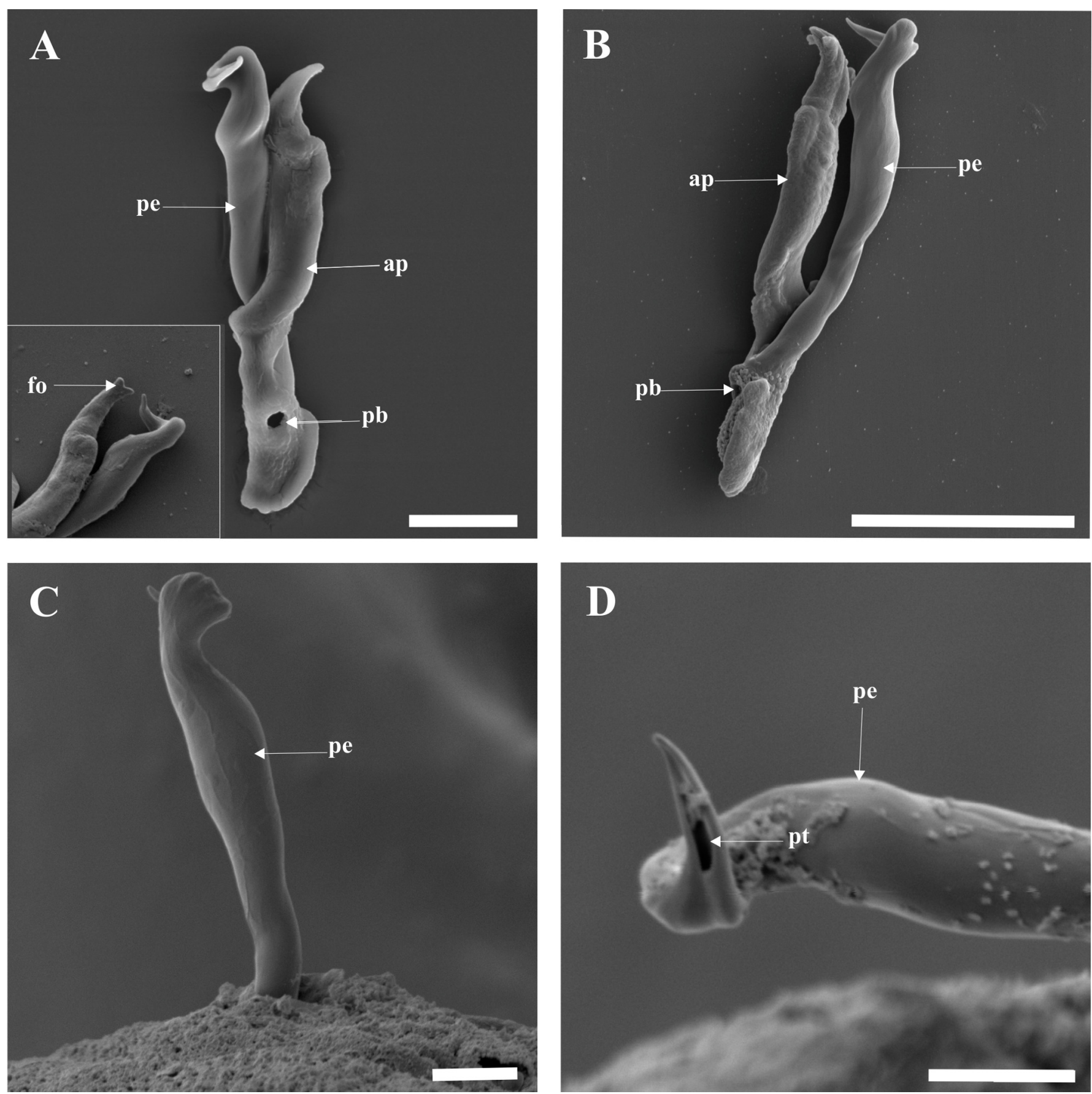

Figure 3. SEM micrographs: A, A insert and B MCO from digested tissue; $\mathbf{C}$ MCO within the tissue in lateral view; $\mathbf{D}$ peripheral region of MCO in contralateral view, showing opening at tip of penis. Abbreviations: ap accessory piece; fo forked terminal end of accessory piece; pe penis; pt opening at tip of penis; pb opening at base of penis. Scale-bars: A, A insert, $10 \mu \mathrm{m}$; B, $20 \mu \mathrm{m}$; C-D, $5 \mu \mathrm{m}$.

opening running from the midpoint of the sharp lateral termination to its base (Fig. 3A-D), and to lack a visible vagina. The ventral and dorsal bars have concave and convex surfaces (Fig. 4A-D) with ribs on the ventral surfaces (Fig. 4B, C), and the dorsal bar has fenestrations at the base of the auricles (Fig. 4C). The first pair of uncinuli displays a lateral wing on the left side of the base and a small fenestration on a ball-like structure on the lateral wing (Fig. 5C). These mentioned features were not visible with light microscopy. The sequence data for this taxon are also distinct from all other Cichlidogyrus species sequence data, based on the $28 \mathrm{~S}$ rDNA, ITS1 rDNA and COI mtDNA.

\section{Discussion}

Sclerotized structures such as the copulatory organs and haptoral parts remain the key features for most monogenean morphological taxonomy [12,20,28,30,38]. Therefore, it is of paramount importance to properly describe these structures, including their ultrastructural 

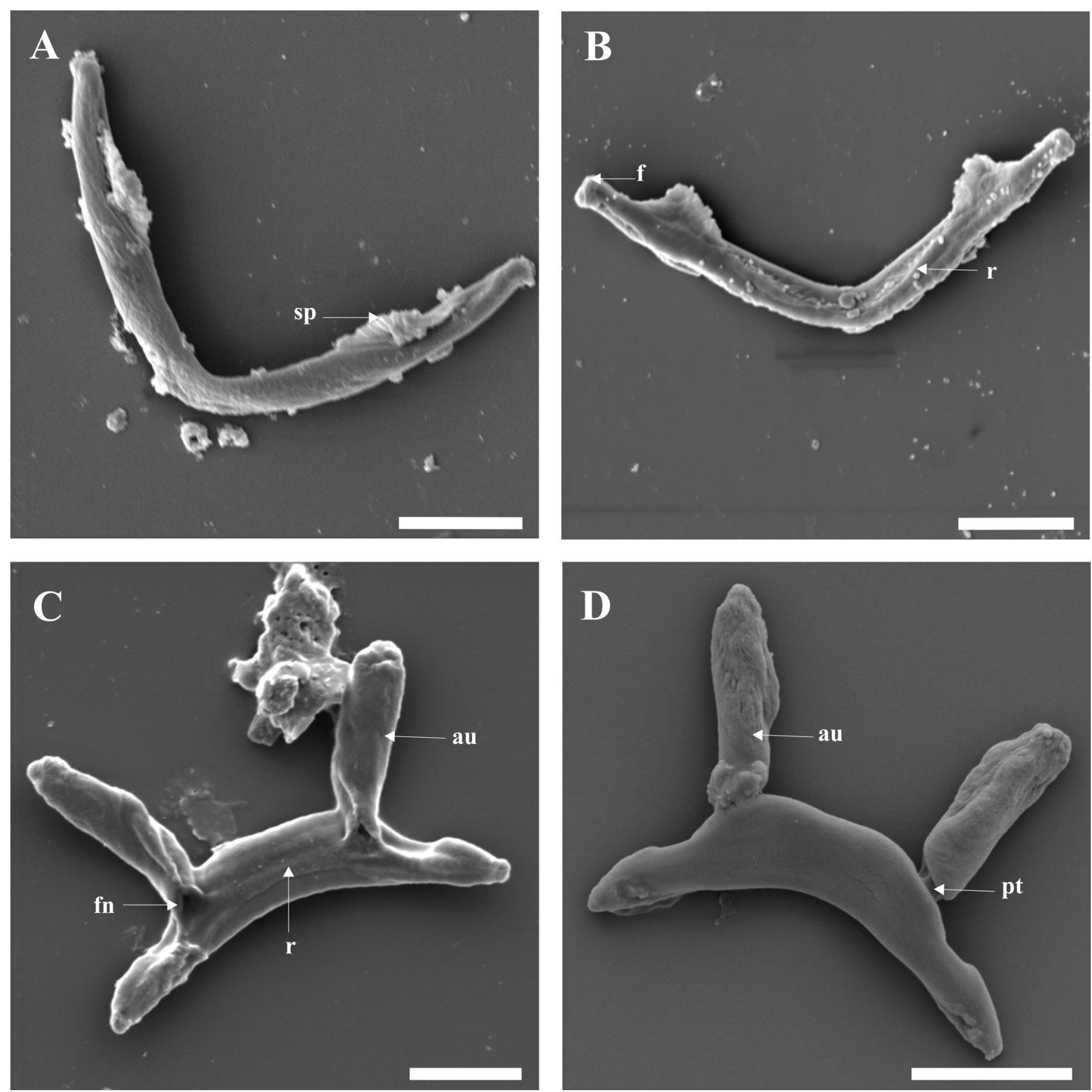

Figure 4. SEM micrographs of ventral and dorsal bars: A convex surface of ventral bar; $\mathbf{B}$ concave surface of ventral bar; $\mathbf{C}$ concave surface of dorsal bar; D convex surface of dorsal bar. Abbreviations: au auricle; f fold on extremities; fn fenestration; pt point of attachment of auricle; $\mathbf{r}$ rib; sp serrated plate. Scale-bars: $10 \mu \mathrm{m}$.

details. Exposing the hard parts by digesting away the surrounding tissue allows flattening of the sclerites and SEM examination of the surface details. The digested tissue also provides genetic material for molecular characterization $[2,21]$.

In this study, $C$. philander, a minute parasite of $P$. philander [3,15], was redescribed. The redescription was based on SEM examination of exposed sclerites, revealing previously undescribed structures on the MCO, the transverse bars and the uncinuli I. For example, the distal part of the penis was shown to form a $360^{\circ}$ curve and ends in a lateral termination with an opening near the middle (Fig. 3D). The opening at the base of the penis (Fig. 3A, B) is probably the entry point of ducts from the vesicula seminalis and prostatic reservoirs as suggested by Fannes et al. [7] for C. casuarinus, but their study did not show an opening at the tip of the penis. These two openings (at the tip and base of the penis) could be a single opening running from the tip to the base of the penis, which makes the penis a hollow organ as depicted in light microscopy (Fig 2A, B). 

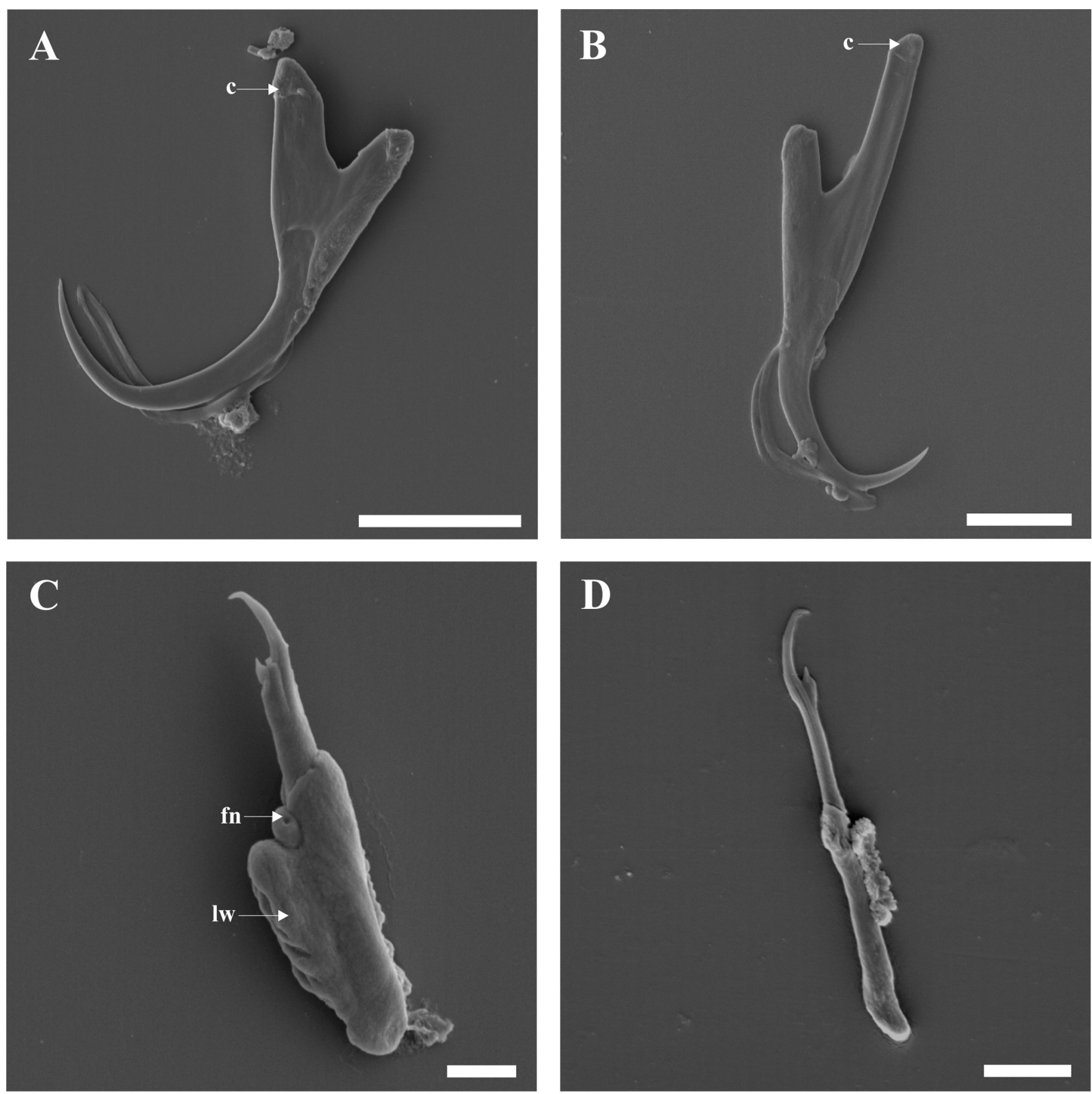

Figure 5. SEM micrographs of gripi (anchors) and uncinuli (hooklets): A ventral gripus: B dorsal gripus; C marginal hooklet I; D marginal hook. Abbreviations: c cap; fn fenestration; lw lateral wing. Scale-bars: A, B $10 \mu \mathrm{m}$; C, D $5 \mu \mathrm{m}$.

Such details can be useful to differentiate species with similar MCOs. This was clearly shown in a study by Fannes et al. [8], which highlighted differences between the genitalia of $C$. tiberianus and Cichlidogyrus dossoui Douëllou, 1993. Another example is the differences observed on the concave surface of the dorsal bars of C. casuarinus in Fannes et al. [7], and $C$. tiberianus and $C$. dossoui in Fannes et al. [8] with $C$. philander in the present study. The concave surface of $C$. casuarinus shows a round structure at the top of the fenestration found at the base of the auricle; $C$. tiberianus shows the same structure, but the structure is at the base of the auricle, while $C$. dossoui and $C$. philander lack this structure. Based on the haptoral configuration proposed by Vignon et al. [37], members of the genus Cichlidogyrus are placed in three main groups (groups A-C) that consists of a given combination of particular uncinuli. C. philander belongs to group B comprising Cichlidogyrus species that have a massive first pair of hooklets and smaller hooks in pair II - VII. The shape of the MCO and isolated haptoral parts corresponds well with the original drawings [3], showing that SEM study does not produce stronger deformations than the conventional light-optical methods. 
Up to $90 \%$ of the digested tissue samples provided sufficient genetic material for amplification and successful sequencing. The uncorrected $p$-distances ranging from $3.16 \%-21.56 \%$ for the three markers confirm the distinctness of $C$. philander from other taxa of the genus. This is supported by the intra- and inter-specific distance ranges for each of the three markers, with the distance of C. philander from other taxa always within the interspecies boundaries. According to the ITS1 topology, the closest Cichlidogyrus taxon to C. philander is an unidentified Cichlidogyrus sp. (KT037335). Vanhove et al. [36] noted that this unidentified Cichlidogyrus sp. sequence and the Cichlidogyrus zambezensis Douëllou, 1993 sequence (COI) were both obtained from parasites collected from Serraochromis robustus jalla Boulenger, 1896 in Zambia. Thus, it seems likely that this unidentified sequence represents $C$. zambezensis. This would mean that $C$. philander and $C$. zambezensis may be closely related based on the ITS1 analysis. However, Vignon et al. [37] placed C. philander and C. zambezensis in different morphological groups. Importantly, in the COI topology, C. philander and C. zambezensis are not closely situated and no $28 \mathrm{~S}$ sequence for $C$. zambezensis is currently available. Similarly, C. casuarinus is more closely situated to $C$. philander in the $28 \mathrm{~S}$ and COI topologies than the ITS1. The large number of sequences not identified to species level makes it difficult to infer the phylogenetic relationships of $C$. philander meaningfully. Future studies incorporating additional sequence data, of particularly correctly identified taxa, and different analytical approaches could lead to more enlightening results.

\section{Acknowledgements}

The authors wish to thank the University of Johannesburg for providing funding. The Spectrum analytical facility and Molecular laboratory of the Zoology Department are acknowledged for allowing us to use their infrastructure. We also thank Dr Beric Gilbert, Dr Lourelle Neethling, Mr Mahlogonolo Molefe and $\mathrm{Mr}$ Nehemiah Rindoria for the different roles they played in this study.

\section{Conflict of interest}

The authors declare that they have no conflict of interest.

\section{References}

1. Dos Santos QM, Jansen van Vuuren B, Avenant-Oldewage A. 2013.Paradiplozoon vaalense n. sp. (Monogenea: Diplozoidae) from the gills of moggel, Labeo umbratus Smith, 1841 in the Vaal River system, South Africa. Journal of Helminthology, 89, 58-67.
2. Dos Santos QM, Avenant-Oldewage A. 2015. Soft tissue digestion of Paradiplozoon vaalense for SEM of sclerites and simultaneous molecular analysis. Journal of Parasitology, 101, 94-97.

3. Douëllou L. 1993. Monogeneans of the genus Cichlidogyrus Paperna, 1960 (Dactylogyridae: Ancyrocephalinae) from cichlid fishes of Lake Kariba (Zimbabwe) with descriptions of five new species. Systematic Parasitology, 25, 159-186.

4. Edgar, RC. 2004. MUSCLE: multiple sequence alignment with high accuracy and high throughput. Nucleic Acids Research, 32, 179-297.

5. Euzet L, Prost M. 1981. Report of the meeting on Monogenea: problems of systematics, biology and ecology, in Review of advances in parasitology, Slusarski W, Editor. PWN, Polish Scientific Publishers: Warsaw. p. 1003-1004.

6. Fankoua SO, Bitja Nyom AR, Bahanak DND, Bilong Bilong CF, Pariselle A. 2017. Influence of preservative and mounting media on the size and shape of monogenean sclerites. Parasitology Research, 116, 2277-2281.

7. Fannes W, Vanhove MPM, Huyse T, Paladini G. 2015. A scanning electron microscope technique for studying the sclerites of Cichlidogyrus. Parasitology Research, 114, 2031-2034.

8. Fannes W, Vanhove MPM, Huyse T. 2017. Redescription of Cichlidogyrus tiberianus Paperna, 1960 and C. dossoui Douëllou, 1993 (Monogenea: Ancyrocephalidae), with special reference to the male copulatory organ. Systematic Parasitology, 94, 133-144.

9. Gussev AV. 1962. Class Monogenoidea, in Key to parasites of freshwater fish of the USSR. Bychovskaya-Pavlovskaya IE et al. Editors. Moscow-Leningrad: Akademiya Nauk SSSR. p. 919. (In Russian: English translation IPST, Ser. No. 1136, Jerusalem, 1964).

10. Hahn C, Bakke TA, Bachmann L, Weiss S, Harris PD. 2011. Morphometric and molecular characterization of Gyrodactylus teuchis Lautraite, Blanc, Thiery, Daniel and Vigneulle, 1999 (Monogenea: Gyrodactylidae) from an Austrian brown trout population. Parasitology International, 60, 480-487.

11. Harris PD, Cable J, Tinsley RC, Lazarus CM. 1999. Combined ribosomal DNA and morphological analysis of individual gyrodactylid monogeneans. Journal of Parasitology, 85, 188-191.

12. Khang TF, Soo OYM, Tan WB, Lim LHS. 2016. Monogenean anchor morphometry: systematic value, phylogenetic signal, and evolution. PeerJ, 4, 1668.

13. Kmentová N, Gelnar M, Koblmüller S, Vanhove MPM. 2016. First insights into the diversity of gill monogeneans of 'Gnathochromis' and Limnochromis (Teleostei, Cichlidae) in Burundi: Do the parasites mirror host ecology and phylogenetic history? PeerJ, 4, 1629.

14. Košková E, Matějusová I, Civánová K, Koubková B. 2010. Ethanol-fixed material used for both classical and molecular identification purposes: Eudiplozoon nipponicum (Monogenea: Diplozoidae) as a case parasite species. Parasitology Research, 107, 909-914.

15. Le Roux LE, Avenant-Oldewage A. 2010. Checklist of the fish parasitic genus Cichlidogyrus (Monogenea), including its cosmopolitan distribution and host species. African Journal of Aquatic Science, 35, 21-36.

16. Le Roux LE, Avenant-Oldewage A, van der Walt FC. 2011. Aspects of the ecology of Cichlidogyrus philander collected from Pseudocrenilabrus philander philander from the Padda Dam, Gauteng, South Africa. African Zoology, 46, 103-116.

17. Librado P, Rozas J. 2009. DnaSP v5: a software for comprehensive analysis of DNA polymorphism data. Bioinformatics, 25, 1451-1452. 
18. Malmberg G. 1957. On the occurrence of Gyrodactylus on Swedish fish. Skrifter Utgivna av Sodra Sveriges Fiskeriforening Arsskrift, 1957, 19-76.

19. Manual of veterinary parasitological laboratory techniques. 1986. Ministry of Agriculture, Fisheries and Food reference book 418. Her Majesty's Stationary Office: United Kingdom. p. 65-66.

20. Mendlová M, Desdevises Y, Civánova K, Pariselle A, Šimková A. 2012. Monogeneans of West African cichlid fish: evolution and copylogenetic interaction. PLoS One 7, e37268. doi:10.1371/jornal.pone.0037268.

21. Messu Mandeng FD, Bilong Bilong CF, Pariselle A, Vanhove MPM, Nyom ARB, Agnèse J. 2015. A phylogeny of Cichlidogyrus species (Monogenea, Dactylogyridea) clarifies a host switch between fish families and reveals an adaptive component to attachment organ morphology of this parasite genus. Parasites and Vectors, 8, 582 .

22. Mo TA, Appleby C. 1990. A special technique for studying haptoral sclerites of monogeneans. Systematic Parasitology, 17, 103-108.

23. Nei M, Kumar S. 2000. Molecular Evolution and Phylogenetics. Oxford University Press, New York.

24. Paperna I. 1960. Studies on monogenetic trematodes in Israel. 2. Monogenetic trematodes of cichlids. Bamidgeh, Bulletin of fish culture in Israel, 12, 2-15.

25. Paperna I. 1979. Monogenea of inland water fish in Africa. Annales du Musée Royal de l'Afrique Centrale, Series 8. Sciences Zoologiques, 226, 1-131.

26. Pariselle A, Euzet L. 1995. Gill parasites of the genus Cichlidogyrus Paperna, 1960 (Monogenea, Ancyrocephalidae) from Tilapia guineensis Bleeker, 1862 with descriptions of six new species. Systematic Parasitology, 30, 187-198.

27. Pariselle A, Euzet L. 2009. Systematic revision of dactylogyridean parasites (Monogenea) from cichlid fishes in Africa, the Levant and Madagascar. Zoosystema, 31, 849-898.

28. Pouyaud L, Desmarais E, Deveney M, Pariselle A. 2006. Phylogenetic relationships among monogenean gill parasites (Dactylogyridea, Ancyrocephalidae) infesting tilapiine hosts (Cichlidae): Systematic and evolutionary implications. Molecular Phylogenetics and Evolution, 38, 241-249.

29. Price CE, Kirk RG. 1967. First description of a monogenetic trematode from Malawi. Revue de Zoologie et de Botanique Africaines, 76, 137-144.
30. Řehulková E, Mendlova M, Šimková A. 2013. Two new species of Cichlidogyrus (Monogenea: Dactylogyridae) parasitizing the gills of African cichlid fishes (Perciformes) from Senegal: morphometric and molecular characterization. Parasitology Research, 112, 1399-1410.

31. Shinn AP, Gibson DI, Sommerville C. 1993. An SEM study of the haptoral sclerites of the genus Gyrodactylus Nordmann, 1832 (Monogenea) following extraction by digestion and sonication techniques. Systematic Parasitology, 25, $135-144$

32. Shinn AP, Gibson DI, Sommerville C. 1995. A study of the composition of the sclerites of Gyrodactylus Nordmann, 1832 (Monogenea) using x-ray elemental analysis. International Journal for Parasitology, 25, 797-805.

33. Stephens M, Smith N, Donnelly P. 2001. A new statistical method for haplotype reconstruction from population data. American Journal of Human Genetics, 68, 978-989.

34. Tamura K, Nei M, 1993. Estimation of the number of nucleotide substitutions in the control region of mitochondrial DNA in humans and chimpanzees. Molecular Biology and Evolution 10, 512-526.

35. Tamura T, Stecher G, Peterson D, Filipski A, Kumar S. 2013. MEGA 6: Molecular Evolutionary Genetics Analysis version 6.0. Molecular Biology and Evolution, 30, 2725-2729.

36. Vanhove MPM, Pariselle A, Van Steenberge M, Raeymaekers JAM, Hablützel PI, Gillardin C, Hellemans B, Breman FC, Koblmüller S, Sturmbayer C, Snoeks J, Volckaert FAM, Huyse T. 2015. Hidden biodiversity in an ancient lake: phylogenetic congruence between Lake Tanganyika tropheine cichlids and their monogenean flatworm parasites. Scientific Reports, 5, 13669.

37. Vignon M, Pariselle A, Vanhove MPM. 2011. Modularity in attachment organs of African Cichlidogyrus (Platyhelminthes: Monogenea: Ancyrocephalidae) reflects phylogeny rather than host specificity or geographic distribution. Biological Journal of the Linnean Society, 102, 694-706.

38. Wu XY, Chilton NB, Zhu XO, Xie MO, Li AX. 2005. Molecular and morphological evidence indicates that Pseudorhabdosynochus lantauensis (Monogenea: Diplectanidae) represents two species. Parasitology, 130, 669677 .

Cite this article as: Igeh PC, Dos Santos QM, Avenant-Oldewage A. 2017. Redescription of Cichlidogyrus philander (Monogenea, Ancyrocephalidae) using scanning electron microscopy (SEM) and molecular analysis. Parasite 24, 49

Reviews, articles and short notes may be submitted. Fields include, but are not limited to: general, medical and veterinary parasitology; morphology, including ultrastructure; parasite systematics, including entomology, acarology, helminthology and protistology, and molecular analyses; molecular biology and biochemistry; immunology of parasitic diseases; host-parasite relationships; ecology and life history of parasites; epidemiology; therapeutics; new diagnostic tools.

All papers in Parasite are published in English. Manuscripts should have a broad interest and must not have been published or submitted elsewhere. No limit is imposed on the length of manuscripts.

Parasite (open-access) continues Parasite (print and online editions, 1994-2012) and Annales de Parasitologie Humaine et Comparée (1923-1993) and is the official journal of the Société Française de Parasitologie. 
Appendix 1

Appendix 1.1 Bootstrap consensus tree based on maximum likelihood, inferred from analysis of the 28S rDNA fragment of Cichlidogyrus philander in relation to other taxa. Values along branches indicate percentage bootstrap support for maximum likelihood and maximum parsimony methods (ML/MP). Nodes without bootstrap values had support lower than $\mathbf{5 0 \%}$ and were omitted or represented with a dash.

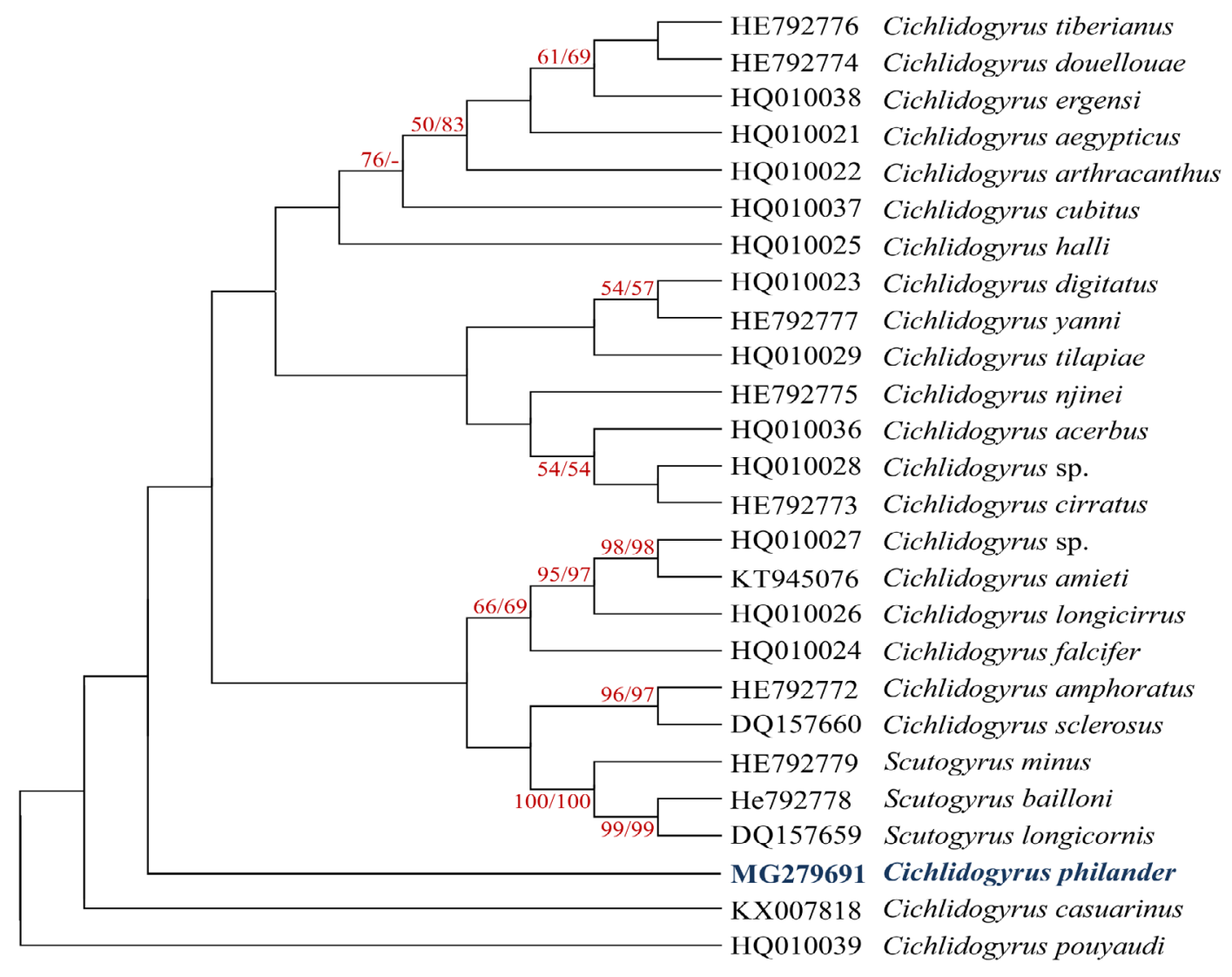


Appendix 1.2 Bootstrap consensus tree based on maximum likelihood, inferred from analysis of the ITS1 rDNA fragment of Cichlidogyrus philander in relation to other taxa. Values along branches indicate percentage bootstrap support for maximum likelihood and maximum parsimony methods (ML/MP). Nodes without bootstrap values had support lower than $\mathbf{5 0 \%}$ and were omitted or represented with a dash.

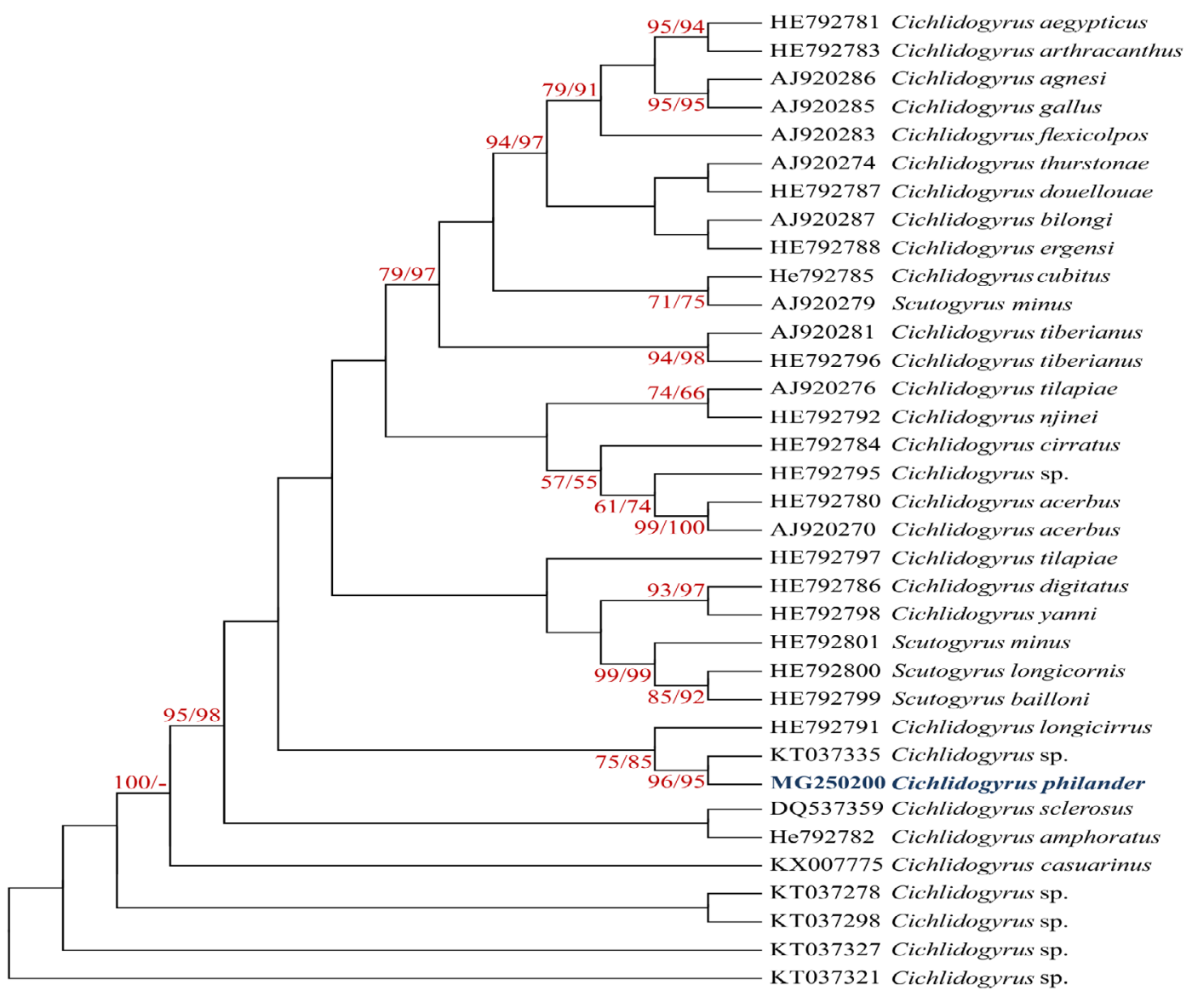


Appendix 1.3 Bootstrap consensus tree based on maximum parsimony, inferred from analysis of the COI fragment of Cichlidogyrus philander in relation to other taxa. Values along branches indicate percentage bootstrap support for maximum likelihood and maximum parsimony methods (ML/MP). Nodes without bootstrap values had support lower than $50 \%$ and were omitted.

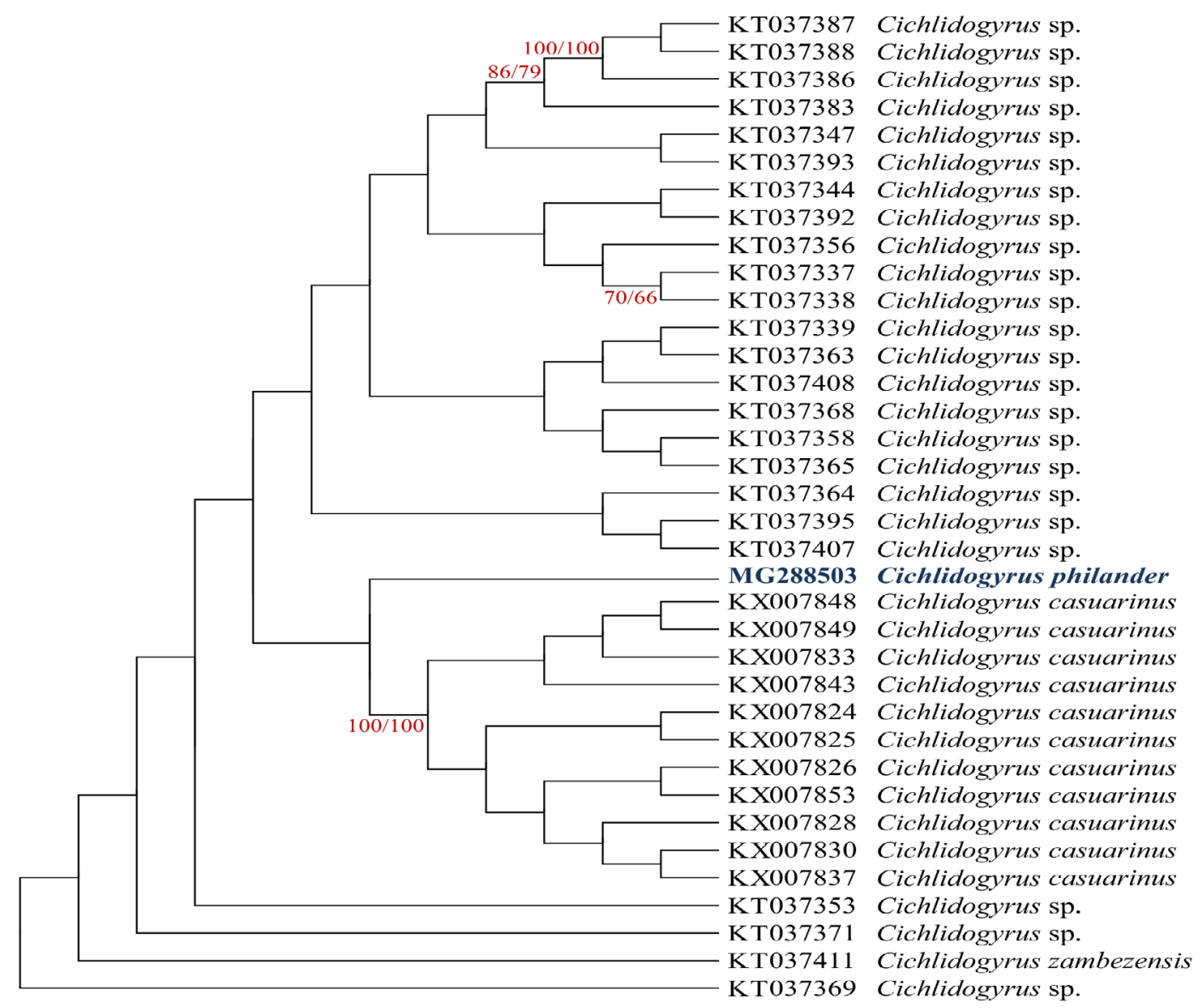


Appendix 2

Appendix 2.1 Genetic distances (\%) between Cichlidogyrus philander and other Cichlidogyrus and Scutogyrus taxa based on the 28S rDNA marker (standard error estimates are shown above diagonal).

\begin{tabular}{|c|c|c|c|c|c|c|c|c|c|c|c|c|c|c|c|c|c|c|c|c|c|c|c|c|c|c|}
\hline & Accession numbers & Species & 1 & 2 & 3 & 4 & 5 & 6 & 7 & 8 & 9 & 10 & 11 & 12 & 13 & 14 & 15 & 16 & 17 & 18 & 19 & 20 & 21 & 22 & 23 & 24 \\
\hline 1 & MG279691 & Cichlidogyrus philander & & 0.69 & 0.70 & 0.75 & 0.71 & 0.75 & 0.74 & 0.79 & 0.80 & 0.77 & 0.80 & 0.82 & 0.80 & 0.83 & 0.81 & 0.84 & 0.81 & 0.83 & 0.91 & 0.86 & 0.94 & 0.91 & 0.90 & 0.9 \\
\hline 2 & HE792775 & Cichlidogyrus njinei & 3.16 & & 0.56 & 0.70 & 0.77 & 0.69 & 0.58 & 0.72 & 0.79 & 0.60 & 0.83 & 0.86 & 0.74 & 0.78 & 0.71 & 0.76 & 0.72 & 0.76 & 0.92 & 0.81 & 0.84 & 0.86 & 0.88 & \\
\hline & HE792777 & Cichlidogyrus yanni & 3.51 & 1.93 & & 0.66 & 0.69 & 0.63 & 0.60 & 0.69 & 0.79 & 0.43 & 0.82 & 0.84 & 0.70 & 0.71 & 0.70 & 0.73 & 0.73 & 0.68 & 0.88 & 0.79 & 0.79 & 0.84 & .83 & \\
\hline 5 & KX007818 & Cichlidogyrus casuarinus & 3.69 & 3.87 & 3.16 & 3.51 & & 0.72 & 0.77 & 0.79 & 0.88 & 0.76 & 0.94 & 0.95 & 0.78 & 0.82 & 0.82 & 0.87 & 0.81 & 0.83 & 0.85 & 0.80 & 0.95 & 0.91 & 0.82 & \\
\hline ס & HQ010022 & Cichlidogyrus arthracanthus & 3.87 & 2.99 & 2.64 & 1.23 & 3.69 & & 0.65 & 0.47 & 0.81 & 0.72 & 0.85 & 0.87 & 0.53 & 0.60 & 0.67 & 0.74 & 0.56 & 0.77 & 0.90 & 0.87 & 0.87 & 0.87 & 0.92 & \\
\hline & HQ010036 & Cichlidogyrus acerbus & 3.87 & 1.93 & 2.28 & 2.81 & 4.04 & 2.81 & & 0.69 & 0.81 & 0.56 & 0.85 & 0.87 & 0.72 & 0.68 & 0.62 & 0.78 & 0.67 & 0.73 & 0.95 & 0.85 & 0.91 & 0.91 & 0.94 & \\
\hline 8 & HE792776 & Cichlidogyrus tiberic & 4.04 & 3.16 & 2.99 & 1.23 & 4.04 & 1.41 & 2.99 & & 0.87 & 0.76 & 0.91 & 0.92 & 0.47 & 0.65 & 0.68 & 0.74 & 0.52 & 0.84 & 0.94 & 0.90 & 0.87 & 0.87 & 0.90 & \\
\hline & HE792779 & Scutogyrus minus & 4.22 & 4.22 & 4.22 & 4.22 & 4.57 & 4.39 & 4.75 & 4.75 & & 0.88 & 0.38 & 0.42 & 0.91 & 0.92 & 0.85 & 0.84 & 0.89 & 0.92 & 0.91 & 0.94 & 1.01 & 0.89 & 0.95 & \\
\hline 10 & HQ010023 & Cichlidogyrus digitatus & 4.22 & 2.28 & 1.23 & 3.51 & 4.04 & 3.51 & 2.11 & 3.69 & 5.10 & & 0.91 & 0.93 & 0.75 & 0.71 & 0.72 & 0.76 & 0.77 & 0.66 & 0.95 & 0.85 & 0.87 & 0.90 & 0.90 & 0. \\
\hline 11 & HQ010035 & Scutogyrus longicornis & 4.39 & 4.75 & 4.75 & 4.75 & 5.10 & 4.92 & 5.27 & 5.27 & 0.88 & 5.62 & & 0.17 & 0.94 & 0.95 & 0.88 & 0.84 & 0.92 & 0.95 & 0.97 & 0.97 & 1.05 & 0.92 & 0.98 & \\
\hline 12 & HE792778 & Scutogyrus bailloni & 4.57 & 4.92 & 4.92 & 4.92 & 5.27 & 5.10 & 5.45 & 5.45 & 1.05 & 5.80 & 0.18 & & 0.96 & 0.97 & 0.90 & 0.86 & 0.94 & 0.96 & 0.98 & 0.98 & 1.06 & 0.92 & 0.99 & 1 . \\
\hline 13 & HE792774 & Cichlidogyrus douellouc & 4.39 & 3.34 & 3.16 & 1.58 & 4.22 & 1.76 & 3.34 & 1.41 & 5.10 & 3.69 & 5.62 & 5.80 & & 0.64 & 0.70 & 0.78 & 0.54 & 0.82 & 0.94 & 0.91 & 0.85 & 0.87 & 0.94 & \\
\hline 14 & HQ010037 & Cichlidogyrus cubitus & 4.39 & 3.69 & 3.34 & 1.93 & 4.39 & 2.28 & 2.99 & 2.46 & 5.27 & 3.34 & 5.80 & 5.98 & 2.64 & & 0.74 & 0.84 & 0.66 & 0.77 & 0.93 & 0.94 & 0.91 & 0.91 & 0.98 & 1. \\
\hline 15 & HE792773 & Cichlidogyrus cirratus & 4.57 & 3.16 & 3.16 & 3.34 & 4.57 & 2.28 & 2.28 & 3.16 & 4.57 & 3.34 & 5.10 & 5.27 & 3.34 & 3.69 & & 0.81 & 0.70 & 0.79 & 0.97 & 0.93 & 0.99 & 0.95 & 0.98 & 1.0 \\
\hline 16 & HQ010024 & Cichlidogyrus falcifer & 4.75 & 3.69 & 3.69 & 3.51 & 4.75 & 2.28 & 4.22 & 3.51 & 4.39 & 4.04 & 4.75 & 4.92 & 4.04 & 4.57 & 4.39 & & 0.75 & 0.83 & 0.97 & 0.76 & 0.87 & 0.85 & 0.79 & 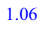 \\
\hline 19 & HE792772 & Cichlidogyrus amphoratus & 5.45 & 5.62 & 5.27 & 5.27 & 4.75 & 2.28 & 6.15 & 5.80 & 5.27 & 6.15 & 5.80 & 5.98 & 6.15 & 5.80 & 6.68 & 5.98 & 6.33 & 6.50 & & 1.02 & 0.99 & 0.78 & 0.99 & 1.0 \\
\hline 20 & HQ010026 & Cichlidogyrus longicirrus & 5.45 & 4.22 & 4.04 & 5.10 & 4.39 & 2.28 & 4.75 & 5.27 & 5.80 & 4.75 & 6.15 & 6.33 & 5.45 & 5.98 & 5.80 & 4.04 & 5.80 & 5.10 & 7.21 & & 0.91 & 0.97 & 0.67 & 1.0 \\
\hline 21 & HQ010025 & Cichlidogyrus halli & 5.80 & 4.39 & 3.87 & 4.75 & 5.62 & 2.28 & 5.10 & 4.92 & 6.85 & 4.92 & 7.38 & 7.56 & 4.75 & 5.62 & 5.98 & 5.45 & 5.45 & 5.80 & 7.03 & 5.62 & & 0.92 & 0.97 & 1.0 \\
\hline 22 & DQ157660 & Cichlidogyrus scleros & 5.80 & 4.92 & 4.92 & 5.10 & 5.10 & 2.28 & 5.80 & 5.27 & 5.10 & 5.62 & 5.62 & 5.80 & 5.45 & 5.45 & 6.33 & 4.75 & 5.80 & 6.15 & 3.69 & 6.50 & 6.15 & & 0.94 & 1.0 \\
\hline 23 & KT945076 & Cichlidogyrus amieti & 5.98 & 5.10 & 4.75 & 5.27 & 4.57 & 2.28 & 5.80 & 5.45 & 5.45 & 5.45 & 5.98 & 6.15 & 5.98 & 6.50 & 6.33 & 4.04 & 6.33 & 4.92 & 6.33 & 3.16 & 6.68 & 6.15 & & \\
\hline 24 & HQ010039 & Cichlidogyrus pouyaudi & 6.15 & 6.50 & 6.15 & 5.80 & 5.80 & 2.28 & 6.50 & 6.33 & 7.38 & 6.33 & 7.91 & 8.08 & 6.50 & 6.15 & 6.33 & 7.21 & 6.85 & 6.15 & 7.73 & 7.91 & 7.73 & 7.56 & 7.73 & \\
\hline
\end{tabular}


Appendix 2.2 Genetic distances (\%) between Cichlidogyrus philander and other Cichlidogyrus and Scutogyrus taxa based on the ITS1 rDNA marker (standard error estimates are shown above diagonal).

\begin{tabular}{|c|c|c|c|c|c|c|c|c|c|c|c|c|c|c|c|c|c|}
\hline & Accession numbers & Species & 1 & 2 & 3 & 4 & 5 & 6 & 7 & 8 & 9 & 10 & 11 & 12 & 13 & 14 & 15 \\
\hline 1 & MG250200 & Cichlidogyrus philander & & 2.12 & 2.23 & 2.20 & 2.23 & 2.22 & 2.31 & 2.28 & 2.33 & 2.25 & 2.29 & 2.32 & 2.33 & 2.31 & 2.3 \\
\hline 2 & KT037335* & Cichlidogyrus sp.* & 12.97 & & 2.06 & 2.12 & 2.18 & 2.33 & 2.18 & 2.28 & 2.25 & 2.30 & 2.19 & 2.24 & 2.25 & 2.31 & 2.27 \\
\hline 3 & DQ537359 & Cichlidogyrus sclerosus & 14.64 & 12.55 & & 1.27 & 1.56 & 1.86 & 1.72 & 1.68 & 1.77 & 1.80 & 1.66 & 1.76 & 1.69 & 1.78 & 1.7 \\
\hline 4 & HE792782 & Cichlidogyrus amphoratus & 14.64 & 13.39 & 4.60 & & 1.63 & 1.99 & 1.63 & 1.76 & 1.74 & 1.89 & 1.78 & 1.86 & 1.64 & 1.85 & 1.8 \\
\hline 5 & HE792796 & Cichlidogyrus tiberianus & 15.90 & 14.23 & 7.11 & 7.53 & & 1.90 & 1.66 & 0.68 & 1.85 & 1.84 & 1.69 & 1.36 & 1.72 & 1.34 & 1.2 \\
\hline 6 & AJ920270 & Cichlidogyrus acerbus & 15.90 & 17.15 & 10.04 & 10.88 & 10.46 & & 1.94 & 1.97 & 2.04 & 0.89 & 2.04 & 1.93 & 2.08 & 2.05 & 1.9 \\
\hline 7 & HE792786 & Cichlidogyrus digitatus & 16.32 & 14.23 & 8.79 & 7.95 & 7.53 & 11.30 & & 1.73 & 1.63 & 1.82 & 1.66 & 1.61 & 1.59 & 1.73 & 1.7 \\
\hline 8 & AJ920281 & Cichlidogyrus tiberianus & 16.32 & 15.48 & 8.37 & 8.79 & 1.26 & 11.72 & 7.95 & & 1.94 & 1.93 & 1.81 & 1.46 & 1.81 & 1.50 & 1.4 \\
\hline 9 & HE792800 & Scutogyrus longicornis & 16.32 & 15.48 & 8.79 & 8.37 & 9.62 & 12.55 & 8.37 & 10.88 & & 2.00 & 1.83 & 1.96 & 1.11 & 2.05 & $2 .($ \\
\hline 11 & HE792797 & Cichlidogyrus tilapiae & 16.32 & 14.64 & 7.95 & 8.79 & 7.53 & 12.13 & 7.53 & 8.79 & 9.62 & 10.88 & & 1.84 & 1.78 & 1.89 & 1.8 \\
\hline 12 & AJ920279 & Scutogyrus minus & 16.74 & 15.90 & 9.62 & 10.46 & 5.44 & 11.72 & 7.11 & 5.86 & 12.13 & 10.46 & 9.21 & & 1.90 & 1.57 & 1. \\
\hline 13 & HE792801 & Scutogyrus minus & 16.74 & 15.48 & 7.95 & 7.53 & 8.79 & 12.97 & 7.95 & 10.04 & 3.35 & 12.13 & 8.79 & 11.30 & & 1.96 & 1. \\
\hline 14 & AJ920274 & Cichlidogyrus thurstonae & 17.15 & 15.90 & 9.21 & 10.04 & 5.02 & 11.72 & 8.37 & 6.28 & 12.55 & 10.46 & 10.04 & 6.69 & 11.72 & & 0.8 \\
\hline 15 & HE792787 & Cichlidogyrus douellouae & 17.15 & 15.48 & 8.79 & 9.62 & 4.18 & 11.30 & 8.37 & 5.44 & 12.13 & 10.04 & 9.21 & 5.86 & 11.30 & 1.67 & \\
\hline 16 & AJ920283 & Cichlidogyrus flexicolpos & 17.15 & 14.23 & 7.11 & 9.62 & 5.44 & 1.72 & 8.37 & 6.69 & 11.30 & 9.62 & 7.95 & 6.69 & 10.46 & 3.77 & 2.9 \\
\hline 17 & HE7 & Cichlidogyrus ergensi & 17.57 & 16.32 & 9.21 & 10.04 & 5.02 & 1.72 & 8.79 & 5.44 & 12.55 & 9.62 & 10.04 & 6.69 & 11.72 & 2.09 & 2.0 \\
\hline 18 & HE7 & gyrus aegypticus & 57 & 14.64 & 7.95 & 10.46 & 5.86 & 12.13 & 9.21 & 7.11 & 12.13 & 10.88 & 8.37 & 7.11 & 11.30 & 3.35 & 2.5 \\
\hline 19 & HE7 & us bailloni & 57 & 16.74 & 8.37 & 7.95 & 9.21 & 12.97 & 8.37 & 10.46 & 1.26 & 12.55 & 9.21 & 11.72 & 3.77 & 12.13 & 11.7 \\
\hline 21 & HE7 & gyrus arthracanthus & 17.57 & 14.64 & 7.95 & 10.46 & 5.86 & 12.13 & 9.21 & 7.11 & 12.13 & 10.88 & 8.37 & 7.11 & 11.30 & 3.35 & 2.5 \\
\hline 22 & KX007775 & Cichlidogyrus casuarinus & 17.99 & 15.06 & 8.37 & 10.46 & 11.30 & 13.39 & 11.72 & 12.55 & 12.97 & 12.55 & 11.72 & 12.55 & 12.97 & 10.88 & 10.4 \\
\hline 23 & AJ920287 & Cichlidogyrus bilongi & 17.99 & 16.74 & 8.79 & 10.46 & 5.44 & 11.30 & 9.21 & 6.69 & 12.97 & 9.21 & 10.46 & 6.69 & 12.13 & 2.93 & 2.9 \\
\hline 24 & AJ920285 & Cichlidogyrus gallus & 18.41 & 14.64 & 8.37 & 10.88 & 6.69 & 12.97 & 9.62 & 7.95 & 12.55 & 10.88 & 9.21 & 7.95 & 11.30 & 4.18 & 3.3 \\
\hline 25 & AJ920286 & Cichlidogyrus agnesi & 18.41 & 14.64 & 8.37 & 10.88 & 6.69 & 12.97 & 9.62 & 7.95 & 12.55 & 10.88 & 9.21 & 7.95 & 11.30 & 4.18 & 3.3 \\
\hline 26 & HE792791 & Cichlidogyrus longicirrus & 18.83 & 17.15 & 13.81 & 13.81 & 14.64 & 18.41 & 15.48 & 15.90 & 16.32 & 17.99 & 15.06 & 15.90 & 14.64 & 15.90 & 15.4 \\
\hline 27 & HE792785 & Cichlidogyrus cubitus & 18.83 & 16.74 & 11.30 & 10.88 & 5.86 & 14.23 & 9.21 & 7.11 & 12.13 & 12.97 & 10.04 & 5.86 & 12.13 & 8.37 & 7.5 \\
\hline 28 & HE792792 & Cichlidogyrus njinei & 19.25 & 16.32 & 11.30 & 10.88 & 8.79 & 14.64 & 9.21 & 10.04 & 12.13 & 12.55 & 10.04 & 10.88 & 12.13 & 11.30 & 9.6 \\
\hline 29 & HE792784 & Cichlidogyrus cirratus & 19.67 & 17.57 & 10.46 & 10.46 & 9.62 & 10.04 & 9.62 & 10.88 & 12.13 & 7.95 & 9.21 & 11.72 & 12.13 & 11.72 & 11.3 \\
\hline 30 & AJ920276 & Cichlidogyrus tilapiae & 20.08 & 20.50 & 14.23 & 13.81 & 11.72 & 15.48 & 12.13 & 12.13 & 14.23 & 15.06 & 14.23 & 14.23 & 14.64 & 15.48 & 15.0 \\
\hline
\end{tabular}

\begin{tabular}{|c|c|c|c|c|c|c|c|c|c|c|c|c|c|c|c|c|c|}
\hline & Accession numbers & Species & 16 & 17 & 18 & 19 & 20 & 21 & 22 & 23 & 24 & 25 & 26 & 27 & 28 & 29 & 30 \\
\hline 1 & MG250200 & Cichlidogyrus philander & 2.35 & 2.35 & 2.38 & 2.40 & 2.37 & 2.38 & 2.32 & 2.36 & 2.39 & 2.39 & 2.44 & 2.40 & 2.41 & 2.47 & 2.48 \\
\hline 2 & KT037335* & Cichlidogyrus sp.* & 2.21 & 2.34 & 2.26 & 2.30 & 2.29 & 2.26 & 2.20 & 2.37 & 2.22 & 2.22 & 2.34 & 2.30 & 2.34 & 2.38 & 2.51 \\
\hline 3 & DQ537359 & Cichlidogyrus sclerosus & 1.61 & 1.77 & 1.68 & 1.73 & 1.74 & 1.68 & 1.68 & 1.73 & 1.68 & 1.68 & 2.10 & 1.95 & 2.03 & 1.93 & 2.11 \\
\hline 4 & HE792782 & Cichlidogyrus amphoratus & 1.85 & 1.86 & 1.91 & 1.66 & 1.70 & 1.91 & 1.91 & 1.88 & 1.90 & 1.90 & 2.09 & 1.90 & 1.93 & 1.92 & 2.13 \\
\hline 5 & HE792796 & Cichlidogyrus tiberianus & 1.41 & 1.33 & 1.46 & 1.80 & 1.75 & 1.46 & 2.00 & 1.37 & 1.51 & 1.51 & 2.21 & 1.4 & 1.78 & 1.88 & 1.97 \\
\hline 6 & AJ920270 & Cichlidogyrus acerbus & 2.02 & 2.01 & 2.02 & 2.05 & 1.86 & 2.02 & 2.11 & 1.97 & 2.03 & 2.03 & 2.38 & 2.15 & 2.17 & 1.89 & 2.18 \\
\hline 7 & HE792786 & Cichlidogyrus digitatus & 1.81 & 1.78 & 1.86 & 1.62 & 1.14 & 1.86 & 2.02 & 1.84 & 1.88 & 1.88 & 2.26 & 1.75 & 1.78 & 1.80 & 2.02 \\
\hline 8 & AJ920281 & Cichlidogyrus tiberianus & 1.58 & 1.41 & 1.61 & 1.89 & 1.75 & 1.61 & 2.10 & 1.54 & 1.67 & 1.67 & 2.25 & 1.58 & 1.89 & 1.98 & 2.04 \\
\hline 9 & HE792800 & Scutogyrus longicornis & 2.00 & 2.05 & 2.06 & 0.67 & 1.59 & 2.06 & 2.03 & 2.08 & 2.06 & 2.06 & 2.31 & 2.00 & 2.03 & 1.99 & 2.1 \\
\hline 11 & HE792797 & Cichlidogyrus tilapiae & 1.70 & 1.90 & 1.75 & 1.77 & 1.72 & 1.75 & 1.99 & 1.93 & 1.77 & 1.77 & 2.25 & 1.89 & 1.88 & 1.73 & 2.20 \\
\hline 12 & AJ920279 & Scutogyrus minus & 1.57 & 1.54 & 1.62 & 1.93 & 1.70 & 1.62 & 2.05 & 1.53 & 1.66 & 1.66 & 2.27 & 1.39 & 1.86 & 1.97 & 2.12 \\
\hline 13 & HE792801 & Scutogyrus minus & 1.91 & 1.95 & 1.96 & 1.19 & 1.63 & 1.96 & 2.07 & 1.99 & 1.96 & 1.96 & 2.20 & 1.97 & 1.98 & 1.95 & 2.20 \\
\hline 14 & AJ920274 & Cichlidogyrus thurstonae & 1.2 & 0.88 & 1.14 & 1.99 & 1.89 & 1.14 & 1.99 & 1.09 & 1.26 & 1.26 & 2.30 & 1.68 & 2.00 & 2.04 & 2.2 \\
\hline 15 & HE792787 & Cichlidogyrus douellouae & 1.03 & 0.87 & 0.96 & 1.97 & 1.77 & 0.96 & 1.94 & 1.06 & 1.10 & 1.10 & 2.27 & 1.55 & 1.84 & 1.99 & 2.19 \\
\hline 16 & AJ920283 & Cichlidogyrus flexicolpos & & 1.04 & 0.68 & 1.94 & 1.85 & 0.68 & 1.95 & 0.98 & 0.69 & 0.69 & 2.21 & 1.71 & 1.94 & 1.90 & 2.23 \\
\hline 17 & HE792788 & Cichlidogyrus ergensi & 2.93 & & 1.17 & 1.99 & 1.72 & 1.17 & 1.97 & 0.91 & 1.15 & 1.15 & 2.29 & 1.68 & 1.91 & 1.99 & 2.18 \\
\hline 18 & HE792781 & Cichlidogyrus aegypticus & 1.26 & 3.77 & & 1.99 & 1.89 & 0.00 & 1.99 & 1.18 & 0.78 & 0.78 & 2.23 & 1.75 & 2.02 & 1.98 & 2.33 \\
\hline 19 & HE792799 & Scutogyrus bailloni & 10.88 & 12.13 & 11.72 & & 1.59 & 1.99 & 2.00 & 2.02 & 2.00 & 2.00 & 2.29 & 1.98 & 1.99 & 1.96 & 2.13 \\
\hline 21 & HE792783 & Cichlidogyrus arthracanthus & 1.26 & 3.77 & 0.00 & 11.72 & 9.62 & & 1.99 & 1.18 & 0.78 & 0.78 & 2.23 & 1.75 & 2.02 & 1.98 & 2.3 \\
\hline 22 & KX007775 & Cichlidogyrus casuarinus & 10.88 & 10.46 & 11.30 & 12.55 & 11.30 & 11.30 & & 2.03 & 1.99 & 1.99 & 2.26 & 2.1 & 2.14 & 2.11 & 2.3 \\
\hline 23 & AJ920287 & Cichlidogyrus bilongi & 2.51 & 2.09 & 3.77 & 12.55 & 9.62 & 3.77 & 11.72 & & 1.17 & 1.17 & 2.35 & 1.69 & 1.91 & 1.97 & 2 \\
\hline 24 & AJ920285 & Cichlidogyrus gallus & 1.26 & 3.77 & 1.67 & 12.13 & 10.04 & 1.67 & 11.72 & 3.77 & & 0.00 & 2.25 & 1.77 & 2.02 & 1.98 & 2.30 \\
\hline 25 & AJ920286 & Cichlidogyrus agnesi & 1.26 & 3.77 & 1.67 & 12.13 & 10.04 & 1.67 & 11.72 & 3.77 & 0.00 & & 2.25 & 1.77 & 2.02 & 1.98 & 2.30 \\
\hline 26 & HE792791 & Cichlidogyrus longicirrus & 14.64 & 16.32 & 14.64 & 15.90 & 16.32 & 14.64 & 17.57 & 16.74 & 15.06 & 15.06 & & 2.34 & 2.36 & 2.39 & 2.5 \\
\hline 27 & HE792785 & Cichlidogyrus cubitus & 8.79 & 8.37 & 9.21 & 11.72 & 9.62 & 9.21 & 14.23 & 8.79 & 10.04 & 10.04 & 16.74 & & 1.89 & 2.04 & 2.18 \\
\hline 28 & HE792792 & Cichlidogyrus njinei & 10.88 & 10.46 & 12.13 & 11.72 & 10.46 & 12.13 & 12.97 & 10.88 & 12.13 & 12.13 & 17.15 & 10.88 & & 1.73 & 1.95 \\
\hline 29 & HE792784 & Cichlidogyrus cirratus & 10.04 & 11.30 & 11.30 & 11.72 & 11.30 & 11.30 & 13.39 & 10.88 & 11.30 & 11.30 & 17.99 & 12.97 & 8.37 & & 2.03 \\
\hline 30 & AJ920276 & Cichlidogyrus tilapiae & 15.48 & 14.64 & 16.74 & 14.23 & 13.39 & 16.74 & 17.57 & 15.06 & 16.74 & 16.74 & 20.92 & 14.64 & 11.30 & 12.97 & \\
\hline
\end{tabular}

* Sequence KT037335 Cichlidogyrus sp. not removed due to its close relation to C. philander. 
Appendix 2.3 Genetic distances (\%) between Cichlidogyrus philander and other Cichlidogyrus and Scutogyrus taxa based on the COI marker (standard error estimates are shown above diagonal).

\begin{tabular}{|c|c|c|c|c|c|c|c|c|c|c|c|c|c|c|c|}
\hline & Accession numbers & Species & 1 & 2 & 3 & 4 & 5 & 6 & 7 & 8 & 9 & 10 & 11 & 12 & 13 \\
\hline 1 & MG288503 & Cichlidogyrus philander & & 2.22 & 2.22 & 2.21 & 2.22 & 2.23 & 2.22 & 2.19 & 2.20 & 2.22 & 2.26 & 2.26 & 2.29 \\
\hline 2 & KX007825 & Cichlidogyrus casuarinus & 20.31 & & 0.86 & 0.66 & 0.76 & 0.61 & 0.80 & 0.89 & 2.41 & 0.80 & 0.80 & 0.73 & 0.84 \\
\hline 3 & KX007833 & Cichlidogyrus casuarinus & 20.31 & 2.81 & & 0.75 & 0.61 & 0.76 & 0.82 & 0.74 & 2.34 & 0.73 & 0.69 & 0.66 & 0.76 \\
\hline 5 & KX007848 & Cichlidogyrus casuarinus & 20.63 & 2.19 & 1.25 & 1.25 & & 0.65 & 0.84 & 0.81 & 2.36 & 0.78 & 0.73 & 0.78 & 0.58 \\
\hline 6 & KX007824 & Cichlidogyrus casuarinus & 20.94 & 1.25 & 2.19 & 1.56 & 1.56 & & 0.67 & 0.78 & 2.42 & 0.66 & 0.67 & 0.58 & 0.75 \\
\hline 7 & KX007830 & Cichlidogyrus casuarinus & 20.94 & 2.19 & 2.50 & 2.50 & 2.50 & 1.56 & & 0.69 & 2.38 & 0.59 & 0.72 & 0.68 & 0.94 \\
\hline 8 & $\mathrm{KX} 0$ & Cichlidogyrus casuarinus & 20.94 & 2.81 & 1.88 & 3.13 & 2.50 & 2.19 & 1.88 & & 2.41 & 0.82 & 0.72 & 0.67 & 0.94 \\
\hline 9 & KT03 & Cichlidogyrus zambezensis & 21.25 & 24.38 & 24.06 & 24.38 & 24.38 & 25.31 & 25.00 & 25.00 & & 2.36 & 2.37 & 2.39 & 2.39 \\
\hline 10 & KX007837 & Cichlidogyrus casuarinus & 21.25 & 2.19 & 1.88 & 1.88 & 1.88 & 1.56 & 1.25 & 2.50 & 24.69 & & 0.72 & 0.68 & 0.88 \\
\hline 11 & KX007826 & Cichlidogyrus casuarinus & 21.56 & 2.19 & 1.88 & 2.19 & 1.88 & 1.56 & 1.88 & 1.88 & 24.69 & 1.88 & & 0.66 & 0.93 \\
\hline 12 & KX007828 & Cichlidogyrus casuarinus & 21.56 & 1.88 & 1.56 & 2.19 & 2.19 & 1.25 & 1.56 & 1.56 & 25.00 & 1.56 & 1.56 & & 0.79 \\
\hline 13 & KX007849 & Cichlidogyrus casuarinus & 21.56 & 2.81 & 1.88 & 1.88 & 1.25 & 2.19 & 3.13 & 3.13 & 25.00 & 2.50 & 3.13 & 2.19 & \\
\hline
\end{tabular}

